\title{
Heavy metal solubility in podzolic soils exposed to the alkalizing effect of air pollutants.
}

\section{Haapala, $\mathrm{H}$.}

Elsevier

2001

Haapala, H. et al. 2001. Heavy metal solubility in podzolic soils exposed to the alkalizing effect of air pollutants. Environmental pollution 115 (2001) 33-41

http://hdl.handle.net/1975/179

Downloaded from Helda, University of Helsinki institutional repository.

This is an electronic reprint of the original article.

This reprint may differ from the original in pagination and typographic detail.

Please cite the original version. 


\title{
Heavy metal solubility in podzolic soils exposed to the alkalizing effect of air pollutants
}

\author{
H. Haapala ${ }^{\mathrm{a}, *}$, N. Goltsova ${ }^{\mathrm{b}}$, M. Lodenius ${ }^{\mathrm{a}}$ \\ ${ }^{a}$ Department of Limnology and Environmental Protection, PO Box 62, FIN-00014 University of Helsinki, Finland \\ ${ }^{\mathrm{b}}$ Sankt-Petersburg Research Center for Ecological Safety, Russian Academy of Sciences (SRCES RAN) and Biological Research Institute of Sankt- \\ Petersburg State University, Oranienbaumskoe sh. 2, SbB, Ru-198904, Russia
}

Received 29 September 2000; accepted 30 December 2000

"Capsule": Both acidic and alkaline pollutants must be reduced to prevent availability of heavy metals.

\begin{abstract}
The heavy metal content of pine forest soil was studied near the boundary between Russia and Estonia, an area characterized by large amounts of acidic and basic air pollutants, mainly sulfur dioxide and calcium. Alkalization dominates the processes in soil, since sulfur is adsorbed only in small quantities, and calcium is much better adsorbed. In addition to Ca, great amounts of Al, Fe, $\mathrm{K}$, and $\mathrm{Mg}$ are accumulated in the humus layer due to air pollution. The heavy metal content has increased. The exchangeable content of heavy metals was in many cases much higher in polluted alkaline soils than in non-polluted acidic soils, even the ratio of exchangeable to total metal content being higher in alkaline plots. To avoid a dangerous increase in soluble heavy metal content, it is important to decrease not only the large sulfur emissions of local pollutant sources, but also the alkaline pollutants. A similar concern must be taken into account when liming of acidic forest soils is planned. (C) 2001 Elsevier Science Ltd. All rights reserved.

Keywords: Heavy metal; Soil pH; Air pollutant; Calcium; Pine forest
\end{abstract}

\section{Introduction}

The territories surrounding the boundary of Russia and Estonia are well-known for acidic air pollutants which originate mainly from the power plants of Narva (Synthesis report, 1991). However, alkaline pollutants are even more massive, causing a very exceptional environmental situation (Haapala et al., 1996b). The soil has been polluted by emissions from local sources over areas several thousands of $\mathrm{km}^{2}$ in size (Haapala et al., 1996a; Kaasik, 1996). Almost all epiphytic lichens on Scots pine trunks are missing on an area of 1000 $\mathrm{km}^{2}$, and less severe damage occurs on a much wider area (Goltsova, 1994). The special character of alkaline air pollutants on the study area is indicated by exceptional pine epiphytes, namely the lichen Xanthoria parietina (L.)Th.Fr. and the green alga Trentepohlia umbrina (Chlorophyceae Chaetophorales) which makes pine trunks red (Haapala et al., 1996b). Forest damage

\footnotetext{
* Corresponding author. Tel.: +358-9-19158302; fax: +358-919158462.

E-mail address: heikki.tervahattu@helsinki.fi (H. Haapala).
}

can be seen in many places. However, almost virginal forests occur in wide areas. They act as pollutant sinks, suffering from the pollutants and at the same time reducing their effects.

Alkalization dominates the processes in soil, changing the originally acidic podzolic soil to neutral or even basic (Haapala et al., 1996a). The process is characterized by a weak adsorption of sulfur and a much better adsorption of calcium and a very low content of exchangeable aluminum. The pollutant load of heavy metals on this area is considerable (Goltsova and Vasina, 1993; Liiv et al., 1994; Mäkinen, 1994).

The heavy metals in soils may occur in the following forms: water-soluble, exchangeable, specifically adsorbed, associated with insoluble organic matter, carbonate, oxides of $\mathrm{Fe}, \mathrm{Al}$ and $\mathrm{Mn}$, and layer silicates (Beckett, 1989). It is well-documented that soil acidification leads to cation exchange and increased leaching of base cations, including heavy metals (Ulrich, 1983). Much less is known about what happens to heavy metals during alkalization. In addition to soil $\mathrm{pH}$, many other factors, such as cationic exchange capacity and dissolved organic matter, have an impact on heavy metal 
mobility in alkaline soils (Echeverria et al., 1998; Fotovat and Naidu, 1998; Ma and Uren, 1998; Ulrich et al., 1999).

The aim of the present work was to study heavy metal solubility as a result of the alkalizing impact of air pollutants. Exchangeable and total content of heavy metals were measured in very polluted and in relatively natural pine forests in different horizons of the podzolic soils. It was supposed that as a reverse process to acidification and increased solubility of heavy metals, alkalization of acidic podzolic soils leads to decreased mobility of heavy metals.

\section{Study area, materials and methods}

The investigations were performed in the western part of the Leningrad administrative region (Fig. 1). The area belongs to the mixed-forest subregion of the Atlanticcontinental region (Mandre, 1995). The mean annual temperature is about $+5^{\circ} \mathrm{C}$ and annual precipitation 550 $\mathrm{mm}$. The study area is heavily polluted by energy production and industry (Haapala et al., 1996b). The largest emissions have originated from the energy power plants of Narva in northeastern Estonia which use oil shale containing 50\% inorganic material. Their sulfur dioxide emissions were 141,000 t in 1992 and 97,000 t in 1993 (VTT, 1994). Estimated heavy metal emissions of the two Narva energy plants in 1992-1993 were the following (t year ${ }^{-1}$ ): Pb 31, Cd 0.28, Zn 37, Cu 1.7, Ni 4.9, Cr 7, Co 1.08, As 8.9, Hg 0.018, Mn 57, Mo 2, Se 0.14, Tl 0.15 (VTT, 1994). The Narva power plants are situated just west of the study area. The main direction of the wind is to the northeast toward the study area (Fig. 1).

Less attention has been paid to the dust emissions of the same plants which, in fact, are still more massive, $186,000 \mathrm{t}$ in 1992 and 135,500 $\mathrm{t}$ in 1993 (VTT, 1994). Other large sources of particle emissions are the cement industry in Kunda, northeast Estonia about $100 \mathrm{~km}$ west from Narva (86,000 t in 1990, Kallaste et al., 1992) and Slantsy cement and oil-shale industry on the Russian side (62,800 $t$ in 1990, Haapala et al., 1996b). The particle emissions of Narva, Kunda and Slantsy are together 5-6 times as large as all Finnish particle emissions from industry plus energy production. In addition, several other large particle-emission sources are situated on or near the study area as well as a large-scale mining industry which causes dust emissions.

The studies were performed on 80 sample plots, 41 of them studied more intensively. They were situated in Scots pine Pinus sylvestris (L.) forests, mainly on sandy soils. Similar types of Scots pine forests were selected for the study, but this was not possible in every case, due to different geological conditions and to the effects on vegetation and soil of massive, long-lasting air pollution. In all plots a podzol profile could be detected.
The soil was formed during the last ice age. Geologically the area is divided into two parts: in the north, the underlying ancient rocks are of silicate composition, while in the south, carbonate rocks predominate. The soil in the north is more clearly podzolized, more acidic and contains fewer alkaline cations.

The sample plots were divided into six zones (Table 1; Fig. 1). Total chromium concentrations of soil humus are included in Fig. 1 to demonstrate the heavy metal loads in different zones of the study area. However, only the results of the most polluted zone 1 and the "background" zone 6 are used in this article.

On each of the 41 plots, samples from the humus, eluvial and illuvial horizons were taken during autumn 1994. Two samples on each plot, both of them containing five subsamples, were taken with a cylinder and combined into a single sample (totally 10 subsamples) for each plot and horizon. The samples were air-dried to constant weight. Particle size, water content and organic matter content were studied, and $\mathrm{pH}$ measured in both water $(1: 2 \mathrm{v} / \mathrm{v})$ and $1 \mathrm{M} \mathrm{KCl}(1: 10 \mathrm{v} / \mathrm{v})$ suspensions; $\mathrm{pH}$ was also measured from pine bark samples. Elemental concentrations of $\mathrm{Al}, \mathrm{Ba}, \mathrm{Ca}, \mathrm{Cd}, \mathrm{Cr}, \mathrm{Cu}, \mathrm{Fe}, \mathrm{K}, \mathrm{Mg}$, $\mathrm{Mn}, \mathrm{Na}, \mathrm{Ni}, \mathrm{Pb}, \mathrm{S}, \mathrm{V}$ and $\mathrm{Zn}$ were determined from both $\mathrm{HNO}_{3}$ extractions (total content, see Haapala et al., 1996a) and $1 \mathrm{M}$ ammonium acetate (exchangeable content; 1:10 v/v, pH 4.65; the suspensions were left to stand overnight before being shaken for $1 \mathrm{~h}$ and then filtered) extractions. Exchangeable Al was measured in the KCl-extractions.

Analyses were performed in St. Petersburg in the MECHANOBR ANALIT laboratory, which participates in international intercalibration. An inductively coupled plasma emission spectrophotometer (ICP, PST, BAIRD) and an atomic absorption spectrophotometer (PERKIN ELMER, Model No 5100 PC) were used for the measurements. Exhangeable acidity (EA) was determined for the $0.1 \mathrm{M} \mathrm{BaCl}_{2}$-extractions $(1: 10 \mathrm{v} / \mathrm{v})$ by titration with $\mathrm{NaOH}$ to an endpoint of $\mathrm{pH} 7.00$.

\section{Results and discussion}

\subsection{Total metal content in soil}

The mean total concentrations of heavy metals in soil are not much higher than those in the south-Finnish forest soil (Table 2). In the less polluted zone 6 , the contents of $\mathrm{Cd}, \mathrm{Cu}$ and $\mathrm{Zn}$ are almost similar, whereas $\mathrm{Pb}$ is lower and $\mathrm{Cr}$ and $\mathrm{Ni}$ are somewhat higher in zone 6 compared to the southern Finland. In the case of vanadium, comparable data is available from the whole Leningrad region showing that $\mathrm{V}$ content is relatively low in the whole study area.

The highest content of heavy metals was, in most cases, found in zone 1 , in the nearest vicinity of the 


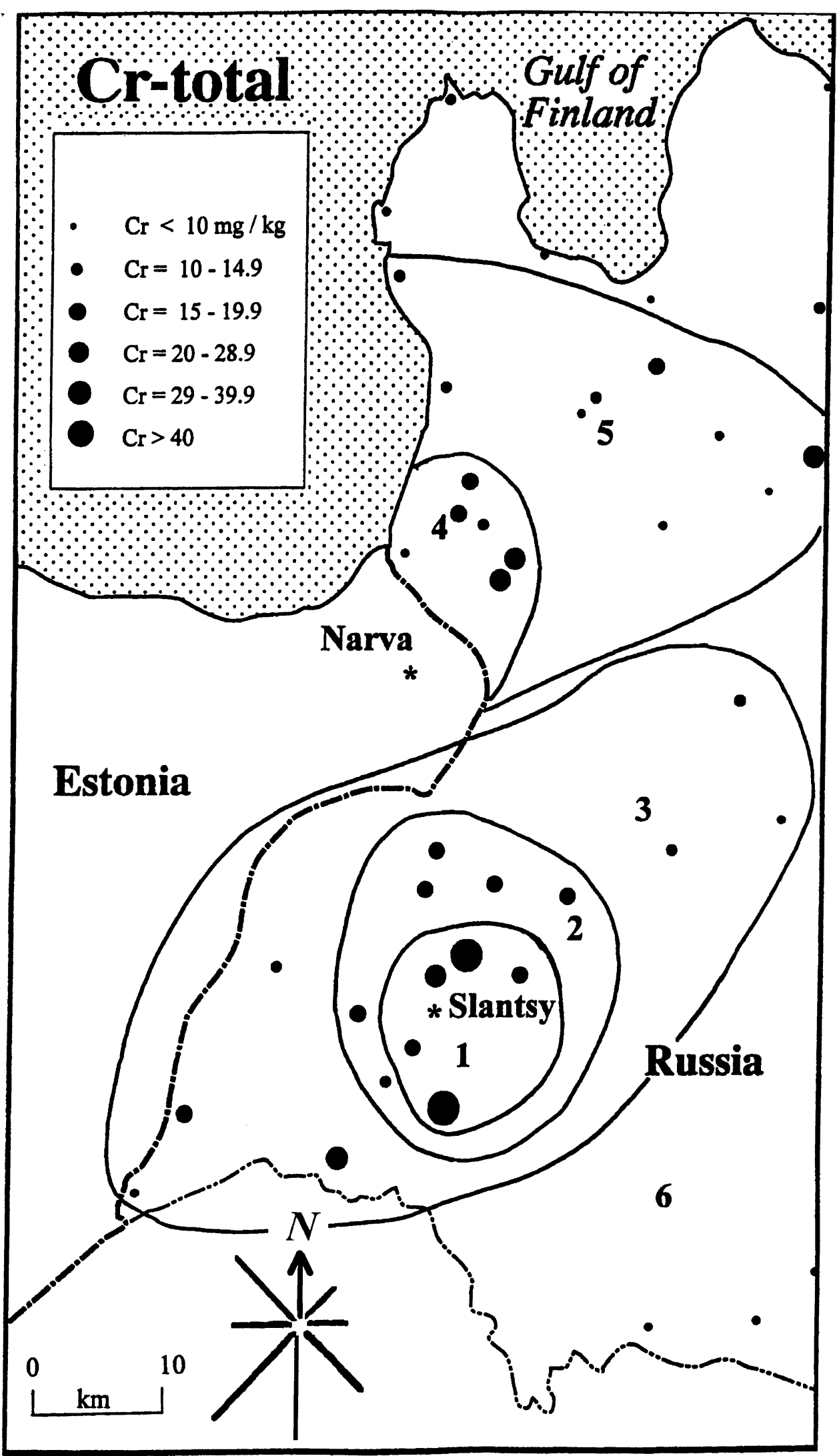

Fig. 1. Study area with two main emission sources, wind directions, six pollutant zones, and total chromium concentrations in humus horizon. Total chromium concentrations of soil humus in the sample plots are included to demonstrate the heavy metal loads in different zones of the study area. 
Table 1

Division of the study area and total chromium content in humus

\begin{tabular}{llcr}
\hline Area & $n$ & Distance from centre $(\mathrm{km})$ & Cr; $\mathrm{mean}(\mathrm{min} .-\mathrm{max}.) \mathrm{mg} / \mathrm{kg}$ \\
\hline 1. First Slantsy-area & 5 & $1-6$ & $29.0(22.1-41.0)$ \\
2. Second Slantsy-area & 6 & $7-20$ & $22.0(17.6-25.5)$ \\
3. Third Slantsy-area & 7 & $15-35$ & $21.6(13.6-31.2)$ \\
4. First Narva-area & 6 & $20-40$ & $24.0(13.0-34.5)$ \\
5. Second Narva-area & 9 & $40-50$ & $16.0(10.7-20.6)$ \\
6."Background" areas & 8 & $11.1(7.9-18.4)$ \\
\hline
\end{tabular}

Table 2

Total element content in humus; study area compared with some other places; mean and min.--max. values (in brackets)

\begin{tabular}{|c|c|c|c|c|c|c|}
\hline \multirow[t]{2}{*}{ Element } & \multicolumn{3}{|l|}{ Study area } & \multirow[t]{2}{*}{ S-Finland ${ }^{\mathrm{a}}$} & \multicolumn{2}{|l|}{ Niepolomice $^{\mathrm{b}}$} \\
\hline & Whole area & Zone 6 & Zone 1 & & Power plant & Cement plant \\
\hline $\mathrm{Cd}, \mathrm{mg} \mathrm{kg}^{-1}$ & $0.51(0.08-1.7)$ & $0.38(0.17-0.57)$ & $0.57(0.45-0.72)$ & $0.4(0-1.6)$ & $(1.0-5)$ & $(1.0-2)$ \\
\hline $\mathrm{Cr}, \mathrm{mg} \mathrm{kg}^{-1}$ & $19(4.9-55)$ & $11(7.9-18)$ & $29(22-41)$ & $7.2(2.7-41)$ & & \\
\hline $\mathrm{Cu}, \mathrm{mg} \mathrm{kg}^{-1}$ & $8.3(2.3-29)$ & $6.6(4.1-9.5)$ & $11(9.8-13)$ & $6.5(3.5-19)$ & $(15-57)$ & $(15-22)$ \\
\hline $\mathrm{Ni}, \mathrm{mg} \mathrm{kg}^{-1}$ & $8.5(1.3-76)$ & $7.9(5.4-13)$ & $16.6(12.3-23.3)$ & $4.8(0-13)$ & & \\
\hline $\mathrm{Pb}, \mathrm{mg} \mathrm{kg}^{-1}$ & $31(4.2-190)$ & $21(7-31)$ & $92(43-180)$ & $37(24-69)$ & $(130-850)$ & $(130-440)$ \\
\hline $\mathrm{Zn}, \mathrm{mg} \mathrm{kg}^{-1}$ & $63(25-152)$ & $56(45-77)$ & $100(76-152)$ & $52(20-160)$ & $(120-690)$ & $(120-400)$ \\
\hline $\mathrm{V}, \mathrm{mg} \mathrm{kg}^{-1}$ & $8.6(0.5-36)$ & $9.3(4.5-12)$ & $24(14-36)$ & & & \\
\hline $\mathrm{Mn}, \mathrm{mg} \mathrm{kg}^{-1}$ & $240(20-1200)$ & $180(17-540)$ & $230(180-350)$ & & $(140-680)$ & $(200-530)$ \\
\hline $\mathrm{Al}, \mathrm{g} \mathrm{kg}^{-1}$ & $4.9(1.1-23)$ & $2.6(2.1-3.7)$ & $14(13-23)$ & & & \\
\hline $\mathrm{Fe}, \mathrm{g} \mathrm{kg}^{-1}$ & $5.9(0.11-20)$ & $4.9(2.9-9)$ & $15(9-20)$ & & & \\
\hline $\mathrm{Ca}, \mathrm{g} \mathrm{kg}^{-1}$ & $12(1.6-97)$ & $6.3(5.4-7.7)$ & $61(36-97)$ & & $(0.27-5.7)$ & $(0.27-22)$ \\
\hline $\mathrm{Mg}, \mathrm{g} \mathrm{kg}^{-1}$ & $0.91(0.18-5.5)$ & $0.51(0.38-0.84)$ & $3.7(2.3-5.5)$ & & & \\
\hline $\mathrm{K}, \mathrm{g} \mathrm{kg}^{-1}$ & $1.6(0.25-12)$ & $0.62(0.37-0.78)$ & $7.6(3.6-12)$ & & $(0.29-0.95)$ & $(0.22-0.68)$ \\
\hline $\mathrm{S}, \mathrm{g} \mathrm{kg}^{-1}$ & $1.0(0.27-3.6)$ & $1.5(0.55-3.6)$ & $1.5(1.3-1.8)$ & & & \\
\hline
\end{tabular}

a Tamminen and Starr (1990).

b Greszta (1988).

Slantsy industrial complex (see $\mathrm{Cr}$ in Fig. 1). In comparison to the south-Finnish forest humus, the heavy metal content in this zone was 1.5- to 4-fold, the difference being highest in the case of $\mathrm{Cr}$ and Ni. Compared to the Niepolomice forest in Poland (Greszta, 1988), the heavy metal contents of the study area were clearly lower, even near Slantsy (Table 2). In Niepolomice, the forest soil was treated with dusts from different industrial sources. However, calcium and potassium contents were much higher in our study area compared to Niepolomice, even in cases where the soil of the Niepolomice forest was artificially polluted by ash from cement plant $(\mathrm{CaO}$ content $47 \%$ ) totaling $75 \mathrm{t} \mathrm{ha}^{-1}$ during 1.5 years. It can thus be concluded that the heavy metal content is increased due to the local air pollutants but is not extremely high.

The maximum metal concentrations in soils permitted under European Union regulations (Wild, 1994) were not exceeded, with the exception of $\mathrm{Ni}$ in one sample plot. The highest contents were (in $\mathrm{mg} \mathrm{kg}^{-1}$; EUmaximum in brackets): $\mathrm{Zn} 152$ (300), $\mathrm{Cu} 29$ (140), Ni 76 (75), Cd 1.7 (3), Pb 190 (300). In very polluted areas, heavy metal concentrations are much higher, for instance near the Severonickel Company smelter in the Kola Peninsula the nickel content of soil has risen to
$4000 \mathrm{mg} \mathrm{kg}^{-1}$ and the copper content to $2000 \mathrm{mg} \mathrm{kg}^{-1}$ (Kryuskov, 1991).

The forest soil of the study area is specially characterized by very high accumulation of alkaline earth and alkali metals. The subject has been previously discussed by the present authors (Haapala et al., 1996a). The Ca concentration in most polluted plots has risen even to $100,000 \mathrm{mg} \mathrm{kg}^{-1}$. The correlation of total soil calcium with $\mathrm{Al}, \mathrm{Fe}, \mathrm{K}, \mathrm{Mg}, \mathrm{Na}$ and $\mathrm{Ba}$ was very significant. Similar extreme soil alkalization has taken place in the surroundings of Kunda and its ecological effects has been reported by Mandre (1995) and Mandre et al. (1999).

On the other hand, sulfur content is not so high as would be expected in the light of the very high emissions. This is obviously due to the low sulfur-adsorption capacity of these podzolic humus soils. On the contrary, the adsorption of calcium is much more efficient. Sulfur as a gaseous emission is also distributed on much wider areas than particulate pollutants thus resulting in smaller deposition concentrations. The result of the whole pollutant deposition is strong alkalization of the soil.

Correlation between total content of different metal elements gives interesting evidence as to the composition 
of pollutant deposition. On the most polluted plots, the airborne pollutant load has a very great effect on the total content of many elements. Concentrations of $\mathrm{Al}, \mathrm{Fe}$, and $\mathrm{Ca}$ are closely correlated in soil humus (Table 3). It can be concluded, that they mainly originate from the same sources. Similarly, heavy metals are positively correlated with $\mathrm{Al}, \mathrm{Fe}$, and $\mathrm{Ca}$ even though the correlation is not significant in some cases. Indeed, the particulate emissions of both Narva energy plants and Slantsy industrial plants contain a lot of $\mathrm{Al}, \mathrm{Fe}$, and $\mathrm{Ca}$ (also much $\mathrm{Si}$, which was not measured) and additionally heavy metals. However, many other factors have an impact on the total element content in soil, namely the quality of soil, the differences in the adsorption capacity, etc. Correlations between different heavy metals vary widely: cadmium even gave negative results with $\mathrm{Cr}$ and $\mathrm{Ni}$, but a significant positive correlation with $\mathrm{Zn}$ and $\mathrm{Cu}$. The highest value was measured between $\mathrm{Cr}$ and $\mathrm{Ni}(r=0.920)$ which elements showed the highest concentrations compared to the southFinnish forest soils (Table 2).

\subsection{Exchangeable metal content in soil}

The relationship of exchangeable and total metal content in humus is dependent on many factors. Since air pollutants have a great effect on the total content of many elements, the chemical form of different pollutants must be taken into account. Some elements may be deposited as unsoluble compounds. In these cases, the ratio of exchangeable to total content is low. On the other hand, air pollutants may react in different ways in soil with organic and inorganic compounds, some of them forming unsoluble compounds and others becoming more soluble. Soil acidity has a great influence on these processes as do redox-potential, moisture and other physical, chemical and biological factors.

For many heavy metals, only a few percent of the total content was found in an exchangeable form. This was true for $\mathrm{Cr}, \mathrm{Cu}, \mathrm{Fe}, \mathrm{Ni}$ and $\mathrm{V}$, but not for $\mathrm{Cd}, \mathrm{Zn}$, and
$\mathrm{Pb}$, Cd having 39\%, $\mathrm{Zn} 19 \%$, and $\mathrm{Pb} 14 \%$ in an exchangeable form (Table 4). The special feature of cadmium has been mentioned by Ferguson (1990) who says that compared with other heavy metals, a significant proportion of cadmium is exchangeable in soil (of the order 20-40\%). Also Ulrich et al. (1999) reported the highest levels of extractable fraction for $\mathrm{Cd}$, moderate for $\mathrm{Zn}$ and low for $\mathrm{Pb}$. For alkaline earth and alkali metals, a relatively high proportion in exchangeable form was found in most cases (Table 4).

The variations in exchangeable/total ratios were interesting for many elements and can best be understood when the most acid zone, 6 (periphery; mean $\mathrm{pH}$ of humus being 4.13, Table 5) and most alkaline zone, 1 (near Slantsy; mean pH of humus 7.55) are compared (Fig. 2a-c). Due to acidification, metal cations are changed to exchangeable and soluble form by the effect

Table 4

The ratio $(\%)$ of soil exchangeable and total element content in the humus horizon of the Scots pine forests in the whole study area, background, and polluted areas

\begin{tabular}{lccc}
\hline Element & Whole area & Background & Polluted \\
\cline { 3 - 4 } & & Zone 6 & Zone 1 \\
\hline $\mathrm{n}$ & 39 & 6 & 5 \\
$\mathrm{Ca}$ & 41 & 40 & 31 \\
$\mathrm{Mg}$ & 29 & 33 & 24 \\
$\mathrm{Ba}$ & 21 & 18 & 17 \\
$\mathrm{~K}$ & 17 & 68 & 6.8 \\
$\mathrm{Na}$ & 25 & 29 & 10 \\
$\mathrm{Mn}$ & 36 & 46 & 48 \\
$\mathrm{Al}$ & 0.8 & 4.7 & 0.1 \\
$\mathrm{Fe}$ & 2.4 & 0.5 & 5.2 \\
$\mathrm{Cd}$ & 39 & 39 & 52 \\
$\mathrm{Zn}$ & 19 & 18 & 16 \\
$\mathrm{Cr}$ & 3.4 & 1.7 & 7.6 \\
$\mathrm{Cu}$ & 2.9 & 2.4 & 4.4 \\
$\mathrm{Ni}$ & 3.1 & 3.6 & 4.9 \\
$\mathrm{~Pb}$ & 14 & 19 & 8.1 \\
$\mathrm{~V}$ & 3.6 & 1.8 & 5.5 \\
$\mathrm{~S}$ & 24 & 7.9 & 20 \\
\hline
\end{tabular}

Table 3

Correlations (Pearson) of total element content in the humus horizon of the Scots pine forests of the study area $(n=78)$

\begin{tabular}{|c|c|c|c|c|c|c|c|c|c|}
\hline & $\mathrm{Al}$ & $\mathrm{Fe}$ & $\mathrm{Ca}$ & $\mathrm{Cd}$ & $\mathrm{Cr}$ & $\mathrm{Cu}$ & $\mathrm{Ni}$ & $\mathrm{Pb}$ & $\mathrm{V}$ \\
\hline $\mathrm{Fe}$ & $0.88^{* * *}$ & & & & & & & & \\
\hline $\mathrm{Ca}$ & $0.90^{* * *}$ & $0.77 * * *$ & & & & & & & \\
\hline $\mathrm{Cd}$ & 0.21 & $0.24 *$ & 0.22 & & & & & & \\
\hline $\mathrm{Cr}$ & $0.42 * * *$ & $0.44 * * *$ & $0.33^{* *}$ & -0.21 & & & & & \\
\hline $\mathrm{Cu}$ & $0.26^{*}$ & $0.38^{* * *}$ & $0.25^{*}$ & $0.50^{* * *}$ & -0.05 & & & & \\
\hline $\mathrm{Ni}$ & $0.29^{*}$ & $0.35^{* *}$ & 0.22 & -0.18 & $0.92^{* * *}$ & 0.05 & & & \\
\hline $\mathrm{Pb}$ & $0.63 * * *$ & $0.53 * * *$ & $0.53 * * *$ & $0.25^{*}$ & 0.21 & $0.32 * *$ & 0.20 & & \\
\hline $\mathrm{V}$ & $0.87^{* * *}$ & $0.76^{* * *}$ & $0.77^{* * *}$ & $0.27^{*}$ & $0.42^{* * *}$ & $0.28^{*}$ & $0.34 * *$ & $0.60^{* * *}$ & \\
\hline $\mathrm{Zn}$ & $0.53 * * *$ & $0.46 * * *$ & $0.55^{* * *}$ & $0.50 * * *$ & 0.09 & $0.51 * * *$ & 0.10 & $0.50 * * *$ & $0.66^{* * *}$ \\
\hline
\end{tabular}

$* P<0.05$.

$* * P<0.01$

$* * * P<0.001$. 
Table 5

Average $\mathrm{pH}$ and exchangeable acidity, aluminum and calcium $(\mathrm{mg} / \mathrm{kg})$ in soil horizons

\begin{tabular}{|c|c|c|c|c|c|c|}
\hline & \multicolumn{3}{|c|}{ Background $(n=8)$} & \multicolumn{3}{|c|}{ Polluted $(n=5)$} \\
\hline & Humus & Eluvial & Illuvial & Humus & Eluvial & Illuvial \\
\hline $\mathrm{pH}$ & 4.13 & 4.25 & 4.76 & 7.55 & 7.35 & 6.32 \\
\hline EA & 5 & 2.03 & 2.29 & 0.9 & 0.32 & 1.52 \\
\hline $\mathrm{Al}$ & 123 & 69 & 313 & 15 & 20 & 62 \\
\hline $\mathrm{Ca}$ & 2540 & 520 & 193 & 19020 & 4190 & 581 \\
\hline
\end{tabular}
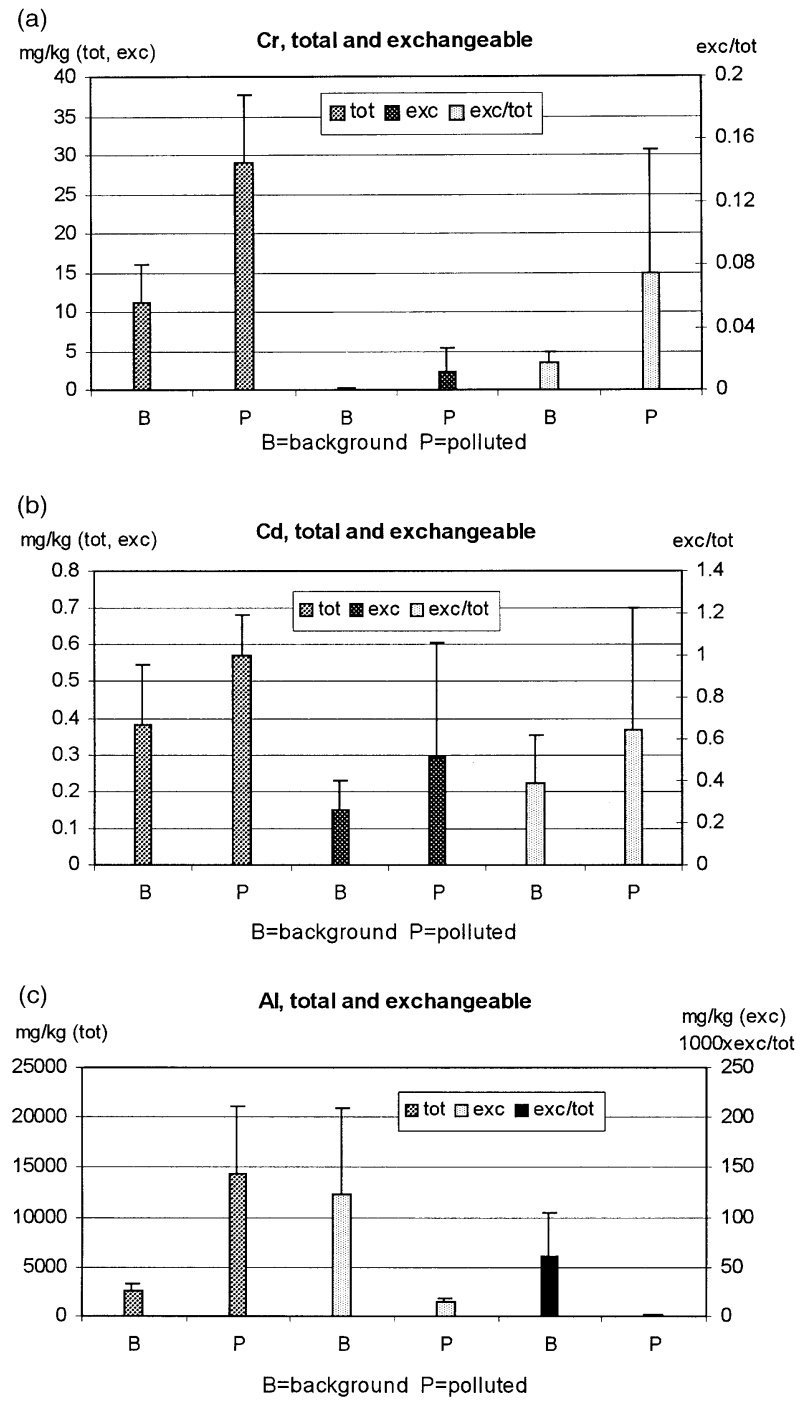

Fig. 2. a-c. Total and exchangeable Cr- (a), Cd- (b), and Al- (c) concentrations and their ratios in humus horizon of the background sample plots (zone 6) and polluted plots (zone 1).

of cation exchange by hydrogen ions. Therefore, the proportion in exchangeable form was supposed to be greater in the acid zone of our study area. This was actually the case in regard to alkaline earth and alkali metals. An even greater difference was observed for aluminum (Fig. 2c), the solubilization of which is strongly dependent on the acidity of soil. Extremely great changes were observed in the ratio of exchangeable $\mathrm{Ca}$ to exchangeable $\mathrm{Al}$ (Haapala et al., 1996a).

In contrast, the proportion of their exchangeable forms was greater in the polluted alkaline soil humus in the case of most heavy metals, namely $\mathrm{Cd}, \mathrm{Cr}, \mathrm{Cu}, \mathrm{Fe}$, $\mathrm{Ni}$ and V (Table 4; Fig. 2a,b). For Zn the proportion was almost similar in both zones. These observations are not in agreement with the generally known fact that many heavy metals are changed into a more soluble form by acidification.

In fact, it is not only the question of acidification/ alkalization in the prevailing conditions. Heavy metal exchangeability in alkaline soils may be increased by cation exchange in which calcium ions have an impact on the solubility of heavy metals (Zhu and Alva, 1993; Echeverria et al., 1998). The concentrations of exchangeable $\mathrm{Ca}$ are very high in our most polluted plots (about 1000-10,000-fold higher than exchangeable concentrations of heavy metals) thus inhibiting the adsorption of heavy metals.

Other processes may also cause the increased exchangeability of heavy metals in alkaline soils. McBride (1989) states that although raising soil $\mathrm{pH}$ reduces the concentration of free metals, the higher $\mathrm{pH}$ promotes the dissolution of soil organic compounds and the formation of soluble metal-organic complexes. Similarly, Göttlein (1988) came to the conclusion that application of excessive amounts of limestone resulted in the dissolution of heavy metals due to the enhanced release of organic complexing agents. Soil organic matter has different effects on heavy metal concentration at different pH-values (Brümmer and Herms, 1983). The organic matter in soils immobilizes heavy metals under strongly acidic conditions (for $\mathrm{Cu}$ and $\mathrm{Pb}$ at $\mathrm{pH}$ values below 4, for $\mathrm{Zn}$ below 5.5, for Cd below 6) and mobilizes metals in weakly acidic to alkaline conditions by forming insoluble or soluble organic metal complexes, respectively. According to Brümmer and Herms (1983), Cu and $\mathrm{Pb}$ concentrations increase at $\mathrm{pH}$ values above 6 or 7 in some soil samples with a higher content of organic matter, because soluble metal organic complexes are formed in this $\mathrm{pH}$ range.

The heavy metals $\mathrm{Pb}$ and $\mathrm{Cu}$ may be mobilized after liming also due to organic compounds formed as a result of stimulated decomposition (Kreutzer et al., 
1989). Because a large part of dissolved organic carbon substances can form metal organic complexes, it is understandable that the concentrations of heavy metals such as $\mathrm{Pb}$ and $\mathrm{Cu}$ increased in the soil solution of the organic layer. $\mathrm{Zn}$ and $\mathrm{Cd}$ may also be concentrated in the forest floor as a result of liming which causes organic matter to diminish (Marschner and Wilczynski, 1991).

Correlations between exchangeable metal element contents in humus also supported the observation of metal element solubilization as a result of increased alkalinisation. $p H$ has a positive correlation with exchangeable calcium content (Table 6). For heavy metals, correlation with $\mathrm{pH}$ is variable. If they were more soluble in acidic soil, they should have a negative correlation with $\mathrm{pH}$, similar to Al. However, the exchangeable content of all heavy metals (except $\mathrm{Pb}$ ) showed an increasing trend with increasing $\mathrm{pH}$, the correlation being significant in the case of $\mathrm{Cr}$ and $\mathrm{V}$.

Also, calcium has a clear positive correlation with heavy metals in the humus layer (Table 5). This observation may support the aforementioned view that ion exchange by $\mathrm{Ca}$ plays an important role in the mobilization of heavy metals.

Exchangeable aluminum showed a totally different behavior having a strong negative correlation both with $\mathrm{pH}$ and with $\mathrm{Ca}$. It is generally known that acidification increases Al-solubility. However, Al-solubility is maintained in higher soil $\mathrm{pH}$ by complexing anions (including organic compunds) and may even be increased in neutral or slightly alkaline soil (Paterson et al., 1991). In the case of liming, the generalized overall reaction in acid soil leads to the precipitation of $\mathrm{Al}^{3+}$ as $\mathrm{Al}(\mathrm{OH})_{3}$. In an idealized complete liming, the soil $\mathrm{pH}$ rises to about 8.3, and complete base saturation is achieved (Thomas and Hargrove, 1984). In the vicinity of Slantsy, soil $\mathrm{pH}_{\mathrm{H}_{2} \mathrm{O}}$ was in many cases 8.3 or near it, and $\mathrm{Ca}$ content of humus rose even to $100 \mathrm{~g} \mathrm{~kg}^{-1}$ (Haapala et al., 1996a). Therefore, it is understandeable that exchangeable $\mathrm{Al}$ content was very low in such conditions.

The correlation coefficients were calculated, in addition to humus, for the eluvial and the illuvial horizons (Table 6). Interesting differences were observed between the horizons, especially between the humus and the illuvial layers. In the latter horizons, most of the heavy metals showed negative correlations with $\mathrm{pH}$, in contrast to the humus layer where the correlation was positive. In the illuvial layer only acid conditions prevailed while humus was in many places alkalized by air pollutants. It is thus supposed that the illuvial layer data indicates the "normal" acid impact which makes the heavy metals more soluble. In the humus horizon, the alkalizing effect is so strong that the correlation is opposite. Calcium did not show any significant correlations with heavy metals in the illuvial horizon.

Exchangeable metal contents are presented in more detail in Fig. 3a-b, which offer information about the different soil horizons and different zones of the study area. The exchangeable element content is much higher in humus than in other layers, especially in polluted areas. Differences between the most and least polluted areas are also very great, metal concentrations being very high in the humus layer of the polluted zone. However, in other horizons, especially in the illuvial layer, the exchangeable metal content was higher in the background area. It can be concluded that pollution from areal sources has a strong effect on the high element-content in humus. This was especially true in zone 1 (nearest the vicinity of Slantsy). The accumulation pattern was, however, not similar for all elements. The differences may have resulted from different pollutant load and from differences in solubility and organic complex formation.

Table 5 gives more information about the acidityalkalinity conditions in different soil horizons of polluted

Table 6

Correlations of $\mathrm{pH}$ and $\mathrm{Ca}$ (logarithmic functions) with exchangeable metal elements (logarithmic functions) in the humus, eluvial and illuvial layers; $n=40$

\begin{tabular}{|c|c|c|c|c|c|c|}
\hline & \multicolumn{2}{|l|}{ Humus } & \multicolumn{2}{|l|}{ Eluvial } & \multicolumn{2}{|l|}{ Illuvial } \\
\hline & $\mathrm{pH}\left(\mathrm{H}_{2} \mathrm{O}\right)$ & $\mathrm{Ca}$ & $\mathrm{pH}\left(\mathrm{H}_{2} \mathrm{O}\right)$ & $\mathrm{Ca}$ & $\mathrm{pH}\left(\mathrm{H}_{2} \mathrm{O}\right)$ & $\mathrm{Ca}$ \\
\hline $\mathrm{Al}$ & $-0.838^{* * *}$ & $-0.566^{* * *}$ & $-0.683^{* * *}$ & $-0.340^{*}$ & $-0.728^{* * *}$ & -0.264 \\
\hline $\mathrm{Cd}$ & 0.078 & $0.528 * * *$ & 0.060 & $0.378^{*}$ & -0.244 & 0.107 \\
\hline $\mathrm{Cr}$ & $0.457^{* *}$ & $0.500^{* * *}$ & 0.013 & 0.118 & -0.191 & 0.070 \\
\hline $\mathrm{Cu}$ & 0.205 & $0.453^{* *}$ & 0.113 & 0.268 & -0.162 & 0.068 \\
\hline $\mathrm{Ni}$ & 0.181 & $0.468^{* *}$ & 0.083 & 0.266 & -0.308 & 0.006 \\
\hline $\mathrm{Pb}$ & -0.187 & 0.282 & -0.292 & 0.141 & $-0.519 * * *$ & -0.004 \\
\hline V & $0.544 * * *$ & $0.606^{* * *}$ & 0.136 & $0.362^{*}$ & -0.121 & 0.223 \\
\hline $\mathrm{Zn}$ & 0.256 & $0.665^{* * *} *$ & -0.144 & 0.148 & -0.194 & -0.298 \\
\hline $\mathrm{pH}$ & & $0.613 * * *$ & & $0.550 * * *$ & & $0.510^{* * *}$ \\
\hline
\end{tabular}

$* P<0.05$

$* * P<0.01$

$* * * P<0.001$. 

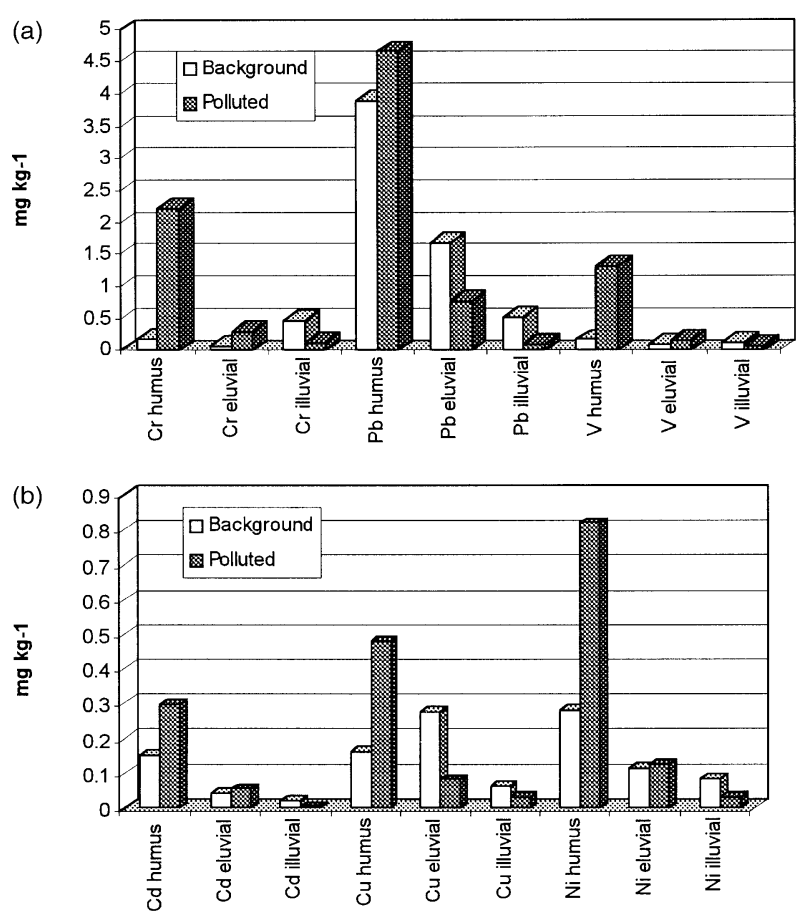

Fig. 3. (a). Exchangeable $\mathrm{Cd}-, \mathrm{Cu}-$, and $\mathrm{Ni}$-content in soil horizons in the background (zone 6) and the polluted (zone 1) sample plots. (b). Exchangeable $\mathrm{Cr}-, \mathrm{Pb}-$, and $\mathrm{V}$-content in soil horizons in the background (zone 6) and the polluted (zone 1) sample plots.

and non-polluted areas (see also Haapala et al., 1996a). In the most polluted zone $1, \mathrm{pH}$ in humus was above 7 due to massive alkaline pollution, and decreased in the deeper horizons. The opposite situation prevailed in the least polluted plots where humus $\mathrm{pH}$ was even below 4 and $\mathrm{pH}$ was higher in deeper horizons. Exchangeable acidity was accordingly higher in the background plots and their humus layer and very low in the humus and eluvial horizons of the polluted areas. Similarly, exchangeable aluminum content of the upmost layers of polluted plots was low (even though the total content was very high) and much higher in non-polluted samples. In zone 6 , the high content in the illuvial horizon may indicate the process of the movement of podzolization deeper in the soil. On the contrary, exchangeable calcium concentrations were extremely high in the humus of polluted areas and clearly increased also in deeper horizons having an impact on the $\mathrm{pH}$.

\section{Conclusions}

The generally accepted concept as to the role of soil acidification in the solubility of heavy metals - namely that the heavy metals are changed to more soluble form by acidification - is too much simplified. In many cases, the exchangeable content of heavy metals was higher in soils polluted by alkalizing metals than in acid soil, even relative to the total metal content. Heavy metal exchangeability in alkaline soils may be increased by cation exchange due to the very high calcium concentrations. The rise in $\mathrm{pH}$ may also lead to increased microbial degradation of humus and higher content of soluble organic compounds which can form soluble complexes of heavy metals.

These observations are environmentally important. The main measures to decrease air pollution in the study area have been directed toward decreasing the sulfur dioxide pollution. If alkaline pollutants are not decreased at the same time, it is possible that soil alkalization will spread over wider areas. As a result, heavy metals will be in a more exchangeable form and may cause environmental damage. The possibility of dangerous heavy metal mobilization must also be borne in mind when liming of acidified forest soils is planned.

The massive accumulation of $\mathrm{Ca}, \mathrm{Al}, \mathrm{Fe}, \mathrm{K}$, and $\mathrm{Mg}$ in the same sample plots in the surroundings of Slantsy indicates the very great effect of local pollutant sources. The content of heavy metals was increased in the same places, but not to a very high level. However, since heavy metals are mobilized into soluble form under the conditions prevailing in the study area, it is possible that some part of them is transferred to the groundwater and to water ecosystems.

\section{Acknowledgements}

We are very thankful to Elena Proletarskaja from the Mechanobr Analit company for the chemical analyses. We also thank Anastasia Galkina for her help in field and laboratory work; Antti Haapala, MSc, for his help in the field work; Hannele Pulkkinen, MSc, for information service; Carol Norris, $\mathrm{PhD}$, for revising the English language of this paper. Thanks are also due to Pentti Välipakka, PhD, the leader of Helsinki University's Kotka Unit, to Anatoly L. Chiruk and Valentina I. Volkova, main local inspectors of LenComEcology, to J.J. Bogdanov and L.G. Chilikin, mayors of Kingisepp and Slantsy, for their help and support.

\section{References}

Beckett, P.H.T., 1989. The use of extractants in studies on trace metals in soils, sewage sludges, and sludge-treated soils. Advances in Soil Science 9, 143-176.

Brümmer, G., Herms, U., 1983. Influence of soil reaction and organic matter on the solubility of heavy metals in soil. In: Ulrich, B., Pankrath, J. (Eds.), Effects of Accumulation of Air Pollutants in Forest Ecosystems. D. Reidel Publishing Company, Dordrecht, pp. 233-243.

Echeverria, J.C., Morera, M.T., Mazkiaran, C., Garrido, J.J., 1998. Competitive sorption of heavy metals by soils. Isotherms and 
fractional factorial experiments. Environmental Pollution 101 (2), 275-284.

Ferguson, J.E., 1990. The Heavy Elements: Chemistry, Environmental Impact and Health Effects. Pergamon Press, Oxford.

Fotovat, A., Naidu, R., 1998. Changes in composition of soil aqueous phase influence chemistry of indigenous heavy metals in alkaline sodic and acidic soils. Geoderma 84 (1), 213-234.

Goltsova, N., 1994. Studies on the Effects of Airborne Pollutants of Estonian Power Plants on Kingisepp and Slantsy Regions (Report on Russian). St Petersburg State University, Russia.

Goltsova, N., Vasina, T.V., 1993. Heavy metals retention by the woodland moss Pleurozium shreberi, Leningrad region survey. Journal of Ecological Chemistry 1, 51-60.

Greszta, J., 1988. Effect of dusts from selected industrial plants on chemical properties of soils. In: Greszta, J. (Ed.), Detrimental Effects of Dusts Emitted by Various Industries on Trees and Forest Biotope. Scientific Papers of Krakóv Agricultural Academy, Poland, pp. 22-64.

Göttlein, A., 1988. Einfluss von saurer Beregnung und Kalkung auf wasserlösliche organische Stoffe eines Waldbodens unter Fichte: methodische und ökologische Untersuchungen im Rahmen des Freilandexperimentes Höglwald. Ludwig-Maximilian-Universität, München.

Haapala, H., Goltsova, N., Pitulko, V., Lodenius, M., 1996a. The effects of simultaneous large acidic and basic pollution on forest soil. Environmental Pollution 94 (2), 159-168.

Haapala, H., Goltsova, N., Seppälä, R., Huttunen, S., Kouki, J., Lamppu, J., Popovichev, B., 1996b. Ecological condition of forests around the eastern part of the Gulf of Finland. Environmental Pollution 91 (2), 253-265.

Kaasik, M., 1996. Atmospheric transport and deposition of technogenic calcium: model estimation and field measurement. Proceedings of the Estonian Academy of Sciences. Ecology 6, 41-51.

Kallaste, T., Roots, O., Saar, J., Saare, L., 1992. Air Pollution in Estonia 1985-1990 (Environmental Report 3). Environmental Data Centre, National Board of Waters and the Environment, Helsinki, Finland.

Kreutzer, K., Reiter, H., Schierl, R., Göttlein, A., 1989. Effects of acid irrigation and liming in a Norway spruce stand (Picea abies [L.] Karst.). Water, Air, and Soil Pollution 48, 111-125.

Kryuskov, V.V., 1991. Heavy metal accumulation in spruce needles and changes of northern taiga ecosystems. In: Pulkkinen, E. (Ed.), Environmental Geochemistry in Northern Europe. Geological Survey of Finland 9, 177-184.

Liiv, S., Sander, E., Eensaar, R., 1994. Territorial distribution of heavy metals content in Estonian mosses. Methodological investigation. Journal of Ecological Chemistry 3 (2), 101-110.

Ma, Y.B., Uren, N.C., 1998. Transformations of heavy metals added to soil - application of a new sequential extraction procedure. Geoderma 84 (1), 157-168.

Mäkinen, A., 1994. Laskeuman seuranta bioindikaattoreiden avulla Koillis-Virossa ja Leningradin oblastin länsiosassa v. 1992-1993. (Biomonitoring of Atmospheric Deposition in North-Eastern Estonia and in Western Parts of Leningrad Oblast in 1992 1993). Loppuraportti Uudenmaan lääninhallitukselle, Helsinki, Finland.

Mandre, M. (Ed.), 1995. Dust Pollution and Forest Ecosystems. A Study of Conifers in an Alkalized Environment. Institute of Ecology, Publications 3/1995, Tallinn.

Mandre, M., Klõšeiko, J., Ots, K., Tuulmets, L., 1999. Changes in phytomass and nutrient partitioning in young conifers in extreme alkaline growth conditions. Environmental Pollution 105 (2), 209-220.

Marschner, B., Wilczynski, A.W., 1991. The effect of liming on quantity and chemical composition of soil organic matter in a pine forest in Berlin, Germany. Plant and Soil 137, 229-236.

McBride, M.B., 1989. Reactions controlling heavy metal solubility in soils. Advances in Soil Sciences 10, 1-56.

Paterson, E., Goodman, B.A., Farmer, V.C., 1991. The chemistry of aluminium, iron and manganese oxides in acid soils. In: Ulrich, B., Sumner, M.E. (Eds.), Soil Acidity. Springer-Verlag, BerlinHeidelberg, pp. 97-124.

Synthesis report, 1991. Environmental priority action programme for Leningrad, Leningrad Region, Karelia and Estonia. Ministry of the Environment of Finland, Helsinki.

Tamminen, P., Starr, M.R., 1990. Survey of forest soil properties related to soil acidification in southern Finland. In: Kauppi, P., Anttila, P., Kenttämies, K. (Eds.), Acidification in Finland. Springer, Berlin, Germany, pp. 235-251.

Thomas, G.W., Hargrove, W.L., 1984. Chemistry of soil acidity. In: Adams, F. (Ed.), Soil Acidity and Liming, 2nd Edition. Agronomy 12. Wisconsin, Madison, pp. 3-56.

Ulrich, B., 1983. Soil acidity and its relations to acid deposition. In: Ulrich, B., Pankrath, J. (Eds.), Effects of Accumulation of Air Pollutants in Forest Ecosystems. Reidel, Dordrecht, pp. 127-146.

Ulrich, S.M., Ramsey, M.H., Helios-Rybicka, E., 1999. Total and exchangeable concentrations of heavy metals in soils near Bytom, an area of $\mathrm{Pb} / \mathrm{Zn}$ mining and smelting in Upper Silesia, Poland. Applied Geochemistry 14 (2), 187-196.

VTT, 1994. Emissions from Estonian and Baltic oil-shale power plant. Final report. Helsinki, Finland.

Wild, A., 1994. Soils and the Environment: an Introduction. Cambridge University Press, Cambridge.

Zhu, B., Alva, A.K., 1993. Differential adsorption of trace metals by soils as influenced by exchangeable cations and ionic strength. Soil Science 155 (1), 61-66. 